\title{
Front Matter: Volume 11592
}

, "Front Matter: Volume 11592," Proc. SPIE 11592, Nondestructive Characterization and Monitoring of Advanced Materials, Aerospace, Civil Infrastructure, and Transportation XV, 1159201 (4 May 2021); doi: 10.1117/12.2597425 


\section{Nondestructive Characterization and Monitoring of Advanced Materials, Aerospace, Civil Infrastructure, and Transportation XV}

Tzu-Yang Yu Andrew L Gyekenyesi

Editors

22-26 March 2021

Online Only, United States

Sponsored and Published by

SPIE 
The papers in this volume were part of the technical conference cited on the coverand title page. Papers were selected and subject to review by the editors and conference program committee. Some conference presentations may not be available for publication. Additional papers and presentation recordings may be a vaila ble online in the SPIE Digital Libra ry at SPIEDigita lLibrary.org.

The papers reflect the work and thoughts of the authors and a re published herein as submitted. The publisher is not responsible for the valid ity of the information or for any outc omes resulting from reliance thereon.

Please use the following format to cite material from these proceedings: Author(s), "Title of Paper," in Nondestructive Characterization and Monitoring of Advanced Materia Is, Aerospace, Civil Infrastructure, and Transportation XV, edited by Tzu-Yang Yu, Andrew L Gyekenyesi, Proc. of SPIE 11592, Seven-digit Artic le CID Number (DD/MM/YYYY); (DOI URL).

ISSN: 0277-786X

ISSN: 1996-756X (electronic)

ISBN: 9781510640139

ISBN: 9781510640146 (electronic)

Published by

\section{SPIE}

P.O. Box 10, Bellingham, Washington 98227-0010 USA

Telephone +1 3606763290 (Pacific Time)

SPIE.org

Copyright @ 2021 Society of Photo-Optic al Instrumentation Engineers (SPIE).

Copying of material in this book for intemal or personal use, or for the intemal or personal use of specific clients, beyond the fair use provisions granted by the U.S. Copyright Law is authorized by SPIE subject to payment of fees. To obta in permission to use and sha re articles in this volume, visit Copyright Clearance Center at copyright.com. Other copying for republic ation, resale, advertising or promotion, or any form of systematic or multiple reproduction of any material in this book is prohibited except with permission in writing from the publisher.

Printed in the United States of America by Curran Associates, Inc., under lic ense from SPIE.

Publication of record for individual papers is online in the SPIE Digital Library.

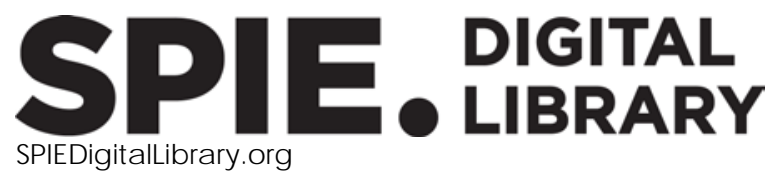

\footnotetext{
Paper Numbering: A unique c itation identifier (CID) number is assigned to each article in the Proceedings of SPIE at the time of public ation. Utilization of CIDs allows artic les to be fully citable as soon as they are published online, and connects the same identifier to all online and print versions of the public ation. SPIE uses a seven-digit CID a rticle numbering system structured as follows:

- The first five digits correspond to the SPIE volume number.

- The last two digits indic ate public ation orderwithin the volume using a Base 36 numbering system employing both numerals and letters. These two-number sets start with $00,01,02,03,04$, 05, 06, 07, 08, 09, 0A, 0B ... 0Z, followed by 10-1Z, 20-2Z, etc. The CID Number appears on each page of the manuscript.
} 


\section{Contents}

COMBINED USE OF NDE, SHM, AND ACCEERATED STRUCTURAL TESTING FOR CONCRETE BRIDGE DEIERIORATION

1159203 Combined use of NDE, SHM, and accelerated structural testing for better understanding of deterioration processes in concrete bridge decks (Keynote Paper) [11592-1]

RADAR NDE

1159206 Factors affecting the delamination of detectability in GPR images [11592-4]

1159207 Remote moisture quantification of concrete using SAR images and the K-R-I transfom [11592-5]

1159208 Comparing predicted in situ 8-year concrete strength by ground penetrating radarattributes and maturity method [11592-6]

1159209 Detection of subsurface defects in concrete slabs using ground penetrating radar [11592-7]

NEW MATERIALS FOR NDE/ SHM

11592 OB Passive sensing of a microparticle modified hybrid, fiber-reinforced composite [11592-9]

11592 OD Eectromechanical analysis of CRP for real-time structural self-sensing and non-destructive evaluation [11592-11]

\section{NDE/SHM FOR NEW MATERIALS}

11592 OF Acoustic emission to track the damage progress on thin-wall large-scale cement composites: damage mode and the effect of wave attenuation at intact and damage state [11592-14]

\section{ARIIRC IAL INTEUGENCE AND MACHINE LEARNING FOR NDE/SHM}

11592 OG Effect of sampling rates on the accuracy of acoustic-laser technique in defect detection and upsampling using machine leaming [11592-15]

$11592 \mathrm{OH}$ Deep leaming for structural health monitoring under environmental and operational variations [11592-16] 
11592 ol Automated two-stage approach for detection and quantific ation of surface defects in concrete bridge decks [11592-17]

11592 0] Rail neutral temperature estimation using impulse vibration and machine leaming [11592-18]

DIGITAL IMAGE CORREATION (DIC)

11592 OK Identification and comelation of natural pattems using a hybrid BRISK-DIC method [11592-19]

$115920 \mathrm{~L} \quad$ Coarse and fine localized CNN classifier for intelligent DIC preprocessing in large structure health monitoring sample [11592-20]

NEURAL NETWORKS AND STATISTICALMETHODS

1159200 Assessment of flaw detectability using transfer function [11592-23]

11592 OP Damage assessment of RC arch structures using fractal analysis of crack pattems [11592-50]

SIMULATION TECHNIQUES FOR NDE/ SHM

$115920 \mathrm{Q}$ Optimizing raster scanning parameters in nondestruc tive evaluation using simulation of probe sensitivity field [11592-24]

11592 OR Analytical and experimental verification of environmental bamiercoating (EBC) covening crack propagation, failure mechanisms, and life modeling [11592-25]

11592 OV FDTD simulation of near-field scattering pattem of a surface crack in plate-like structures for optimal inspection angle determination [11592-48]

11592 0W An algonithmic framework employing tensor decomposition and Bayesian inference for data reconstruction in intelligent transportation systems [11592-47]

\section{PATIERN RECOGNIION AND OPIIMIZATION IN IMPEDANCE-BASED NDE}

11592 oY Damage study of structures using Hotteling's T2 curve in electromechanical impedance method [11592-30]

NDE FOR MANUFACTURING

$1159210 \quad$ Assessing visual and system flaw detectability in nondestructive evaluation [11592-32]

iv 
$1159211 \quad$ Ultrasonic dispersion and attenuation in bubbly liquids [11592-33]

$1159213 \quad$ Manipulating the torsional mode in pipe-like structures with mechanical lens for extended propagation distance [11592-35]

1159214 Detection of material nonlinearity using nonlinear ultrasonic three-wave mixing technique [11592-36]

VIBRATION-BASED NDE/SHM

1159217 Developed Schmidt hammer based on jerk measurement [11592-51]

\section{POSTER SESSON}

11592 1B Sequential Monte Carlo based predic tion of crack propagations in carbon fiber composites using electrical resistance measurement [11592-42]

11592 1D Short-term mechanical strength prediction of ultra-high performance concrete using noncontact synthetic aperture radarimaging [11592-44]

$115921 \mathrm{E}$ In situ structural validation of components manufactured using fused filament fabrication [11592-45]

$115921 \mathrm{G}$ Optical fiber sensing textile for temperature and strain distributed measurement [11592-52] 
Proc. of SPIE Vol. 11592 1159201-6 Downloaded From: https://www.spiedigitallibrary.org/conference-proceedings-of-spie on 26 Apr 2023
Terms of Use: https://www.spiedigitallibrary.org/terms-of-use 